\title{
EKSISTENSI SISTEM PESANTREN SALAFIYAH DALAM MENGHADAPI ERA MODERN
}

\author{
M. Holil Baita Putra M.Pd.I
}

\begin{abstract}
Abstraksi
Dalam kajian ini akan dipaparkan beberapa hal yang berkaitan tentang eksistensi Sistem Pesantren Salafi dalam Menghadapi Era Modern. Penulisan artikel ini dilatar belakangi oleh keinginan dari penulis untuk mengetahui bagaimana eksistensi Pesantren Salafi di mana ketika zaman terus berubah dan sistem pendidikan saat ini terus berkembang dengan berbagai kurikulum baru dan metode pembelajaran juga ikut berkembang dan berbeda dengan model pembelajaran sebelumnya sehingga dalam hal ini Pesantren khususnya salafi harus dapat menyesuaikan diri dalam menghadapi zaman/Era Modern di mana dituntut setiap lembaga pendidikan tidak kecuali pesantren untuk dapat menyesuaikan dengan keadaan sekarang ini sehingga tidak dijauhkan oleh masyarakat. Tantangan tunggal pesantren di masa modern adalah adanya gesekangesekan globalisasi dan modernisasi yang bersifat kompleks. Dalam menghadapi tantangan zaman, pesantren juga harus senantiasa memegang prinsip-prinsip pembaharuan yaitu: memiliki kebijaksanaan menurut ajaran Islam, memiliki kebebasan yang terpimpin, berkemampuan mengatur diri sendiri, memiliki rasa kebersamaan yang tinggi, menghormati orang tua dan guru, cinta kepada ilmu, mandiri, kesederhanaan. Kata kunci: Pesantren Salafi, Pembaharuan Kurikulum
\end{abstract}




\section{A. Latar Belakang 86}

Dalam pemaparan paper ini akan membahas tentang Sistem Pesantren salafi atau tradisional dalam menghadapi Era Modern; kelebihan dan kekurangannya. Namun penulis akan menjelaskan sepintas berkaitan dengan pengertian, latar belakang dan ciri/karakteristik pesantren salafi. Pesantren (dayah) merupakan lembaga pendidikan tertua di Indonesia, yang tumbuh dan berkembang sejak ratusan tahun lalu, masih eksis dan dibutuhkan kehadirannya di tengah-tengah masyarakat Muslim Indonesia hingga sekarang ini. Namun demikian, eksistensi pesantren sebagai lembaga pendidikan Islam di Indonesia, mendapat berbagai tantangan dan rintangan. Mulai pada masa kolonial Belanda, masa kemerdekaan, masa Orde Baru hingga masa sekarang- pesantren mendapat tekanan yang tidak ringan; seperti marginalisasi peran pesantren, penciptaan stigma negatif, dan perluasan pendidikan sekuler. Selain dari sistem pendidikan Belanda, pendidikan pesantren datang dari eksponen tokoh sekuler pendidikan Indonesia yang memberikan stigma negatif terhadap pesantren, yang menginginkan agar pesantren dihapuskan sebagai bagian dari pendidikan Nasional. Stigma ini bisa saja karena pesantren khususnya salafi dianggap tidak dapat menyesuaikan dengan tuntutan zaman karena dalam berbagai hal pesantren salafi masih mempertahankan tradisinya yang merupakan karakteristiknya di mana pesantren ini menjadi sangat berbeda dengan pesantren modern dan terpadu. Respon pendidikan pesantren terhadap sekolah dan madrasah yang didirikan oleh kaum refomis Islam, adalah "menolak sambil mencontoh". Di satu sisi pesantren menolak asumsi-asumsi kaum reformis dan meman- dangnya sebagai ancaman yang serius terhadap pesantren, namun juga dalam batasbatas tertentu mengikuti dan mencontoh langkah kaum reformis, agar dapat bertahan hidup. Karena itulah, pesantren melakukan langkah-langkah penyesuaian yang mereka yakini akan memberikan 
manfaat bagi kaum santri, dan mendukung keberlangsungan dan kebertahanan pesantren, seperti sistem penjenjangan (klasikal) dan kurikulum yang terencana, jelas dan teratur. ${ }^{1}$ Menurut Zamakhsyari Dhofier, pesantren salaf/tradisional adalah lembaga pesantren yang mempertahankan pengajaran kitabkitab klasik sebagai inti pendidikan. Sistem madrasah ditetapkan hanya untuk memudahkan system sorogan yang dipakai dalam lembaga-lembaga pengajian bentuk lama, tanpa mengenalkan pengajaran pengetahuan umum. Tradisionalisme dalam konteks pesantren harus dipahami sebagai upaya mencontoh tauladan yang dilakukan para ulama shalaf yang masih murni dalam menjalankan ajaran Islam agar terhindar dari bid $^{e} a h$, khurafat, takhayul, serta klenik. Hal ini kemudian lebih dikenal dengan gerakan salaf, yaitu gerakan dari orang-orang terdahulu yang ingin kembali kepada alQurean dan Hadis. Gerakan salaf ini dalam perjalanan sejarahnya telah memberikan sumbangan besar terhadap modernisasi Islam. Gerakan salaf secara sadar menolak anggapan bahwa Islam tidak cocok. Mereka mencari tahu faktor yang menyebabkan ketidakcocokan tersebut, yakni karena taqlid. ${ }^{2}$ Pesantren sebagai pendidikan nonformal adalah sebuah lembaga pendidikan dan penyiaran agama Islam yang tradisional. ${ }^{3}$ Pondok pesantren tradisional juga sebagai basis pendidikan yang tertua di Indonesia karena sejalan dengan perjalanan penyebaran Islam di Indonesia, hal ini dibuktikan dengan telah berdirinya pondok-pondok pesantren sejak abad ke 15, seperti Pesantren Gelogah Arum yang didirikan oleh Raden Fatah pada tahun 1476 sampai pada abad ke19 dengan beberapa pondok-pondok pesantren yang dipimpin oleh para wali, seperti Pesantren Sunan Malik Ibrahim di Gresik, Pesantren Sunan Bonang di Tuban, Pesantren

\footnotetext{
${ }^{1}$ Karel A Steenbrink, Pesantren, Madrasah Sekolah: Pendidikan dalam Kurun Waktu Modern, (Jakarta: LP3ES; 1994), hal. 65-67.

${ }^{2}$ Nawawi, Sejarah Perkembangan Pesantren. Dalam Jurnal Ibda` Vol. 4 No. 1Jan-Jun 2006, hal. 3-4.

${ }^{3}$ Dawam rahardjo, Pergulatan Dunia Pesantren dari bawah (Jakarta: p3m,1985), hal. 34
} 
Sunan Ampel di Surabaya dan PesantrenTegal Sari yang terkemuka di Jawa. ${ }^{4}$

\section{B. Ciri-Ciri Pesantren Tradisional}

Pesantren sebagai lembaga pendidikan Islam tradisional, memiliki ciri-ciri khusus, yang barangkali tidak dimiliki lembaga pendidikan lain di luar pesantren secara umum. Sedangkan istilah tradisional yang menjadi predikat lembaga pendidikan semacam pesantren itu, menurut Zamakhsyari Dhofier adalah suatu kondisi yang masih terikat kuat dengan pikiran-pikiran para ulama ahli fiqh, hadits, tafsir, kalam serta tasawuf, yang hidup antara abad ke tujuh sampai abad ke tiga belas. Walaupun hal itu bukan berarti bahwa pesantrenpesantren tradisional yang hidup dewasa ini tetap terbelenggu dalam bentuk-bentuk pikiran dan aspirasi yang diciptakan ulama pada masa itu. Sebab walaupun semenjak abad 13 sampai akhir 19 perumusan tradisional sedikit sekali mengalami perubahan, namun dalam kenyataannya struktur kehidupan pesantren telah banyak mengalami perubahan. ${ }^{5}$ Tuntutan kehidupan pesantren dengan realitas zaman telah memaksa sementara para tokoh pesantren untuk melakukan studi banding terhadap sistem budaya pesantren dengan budaya kontemporer, yang dengan mengkaitkan modernitas pesantren dan budaya kaum santri, akan memperkuat karakteristik tradisi pesantren dengan tanpa melepas keterkaitannya dengan dunia luar. ${ }^{6}$ Karena seperti dikatakan Kuntowijoyo yang dikutip Zubaidi, bahwa jika pesantren hanya dilihat dari sisi sebuah "lembaga tua", tanpa mengenal watak-watak barunya, maka hal itu tidak

\footnotetext{
${ }^{4}$ Roihan dalam amirudin nahrawi, pembaharuan pendidikan pesantren(yogyakarta: gama media, 2008) hal. 1

${ }^{5}$ Zubaidi Habibullah, Moralitas..., h. 17-18

${ }^{6}$ Zubaidi Habibullah, Moralitas..., h. 19
} 
akan menolong dalam analisis sosial dunia pesantren. ${ }^{7}$ Tradisi pesantren merupakan salah satu bentuk budaya hasil akulturasi budaya Indonesia dengan ajaran Islam. Oleh karena itu tradisi pesantren tidak kita temui selain di Indonesia, khususnya di Pulau Jawa, dimana praktek keislaman masih banyak diwarnai dengan budaya lokal. Oleh karena itu umat Islam di Jawa khususnya dan muslim Indonesia pada umumnya perlu berhatihati serta harus mampu membedakan antara apa yang benarbenar Islam universal dan apa yang Jawa lokal. Karena walaupun akulturasi budaya telah diakui, namun jelas ada perbedaan antara budaya lokal dan universalisme Islam. Dalam hal ini tradisi pesantren mengandung nilai intrinsic Islam yang universal, yaitu kewajiban melaksanakan ajaran agama Islam. Akan tetapl di samping itu ia juga mengandung nilai instrumental yang lokal yaitu model akulturasinya diambil dari budaya Jawa. Sehingga di tempat lain akan sangat mungkin nilai universal Islam itu dilakukan dengan tradisi yang berbeda. Berkaitan dengan dunia pesantren dan pemikiran-pemikirannya itu, Wahid Zaini mengatakan bahwa santri sebagai obyek yang sekaligus subyek pendidikan pesantren itu memiliki tiga ciri pokok yaitu:

1. Relatif memiliki kepedulian terhadap kewajiban-kewajiban ainiah sebagai hamba Allah.

2. Menjaga hubungan baik dengan Allah sebagai Penciptadan Pemiliknya.

3. Menjaga hubungan baik terhadap sesama.

Di samping itu terdapat beberapa aspek lain yang menjadi ciri kehidupan dan pendidikan pesantren. Beberapa aspek itu di antaranya:

1. Pemberian pengajaran dengan metode, struktur dan literatur tradisional, baik dia berupa pendidikan formal di sekolah atau

${ }^{7}$ Zubaidi Habibullah, Moralitas..., h. 25 
madrasah dengan jenjang pendidikan yang bertingkat-tingkat, maupun dengan sistem halaqah, dan sorogan, yang ciri utama dari pengajaran ini adalah penekanan terhadap pemahaman secara harfiah atas suatu kitab tertentu. Hal demikian akan membuat rendahnya daya analisa para santri.

2. Pemeliharaan terhadap nilai tertentu, yang barangkali untuk memudahkan dapat disebut dengan sub kultur pesantren. Tata nilai atau sub kultur dimaksud adalah penekanan kepada nilai ibadah terhadap setiap kegiatan yang dilakukan santri, termasuk taat dan memuliakan guru merupakan sarana untuk memperoleh pengetahuan agama yang hakiki. ${ }^{8}$

Dua ciri pendidikan pesantren sebagai contoh tersebut di atas, jika dilihat dari satu sisi memang mengandung nilai-nilai positif, namun hal itu bukan berarti di dalamnya tidak menyimpan segisegi negatif. Sisi positif dari ciri pendidikan pesantren tersebut di antaranya dapat disebutkan bahwa dengan memiliki sikap hidup yang diciptakan sendiri oleh dunia pesantren dengan dilandasi tata nilai seperti tersebut di atas, santri akan memiliki sikap hidup sendiri yang terlepas dari lingkungan structural yang ada di luar pesantren, yang ada pada gilirannya akan mampu membuat santri hidup mandiri dan lepas dari ketergantungannya terhadap lembaga masyarakat yang manapun. Kemampuan menanamkan prinsip "ibadah" terhadap setiap aktifitas yang dilakukannya sebenarnya merupakan dambaan dari setiap muslim, yang itu barangkali hanyatumbuh suburdi lingkungan pesantren. Hanya saja kurang adanya landasan filsafat pendidikan yang jelas, serta perencanaan yang terperinci dan rasional terhadap proses atau jalannya pendidikan itu sendiri, merupakan kekurangan yang harus dilengkapi dan secara bertahap dan terus menerus disempurnakan. ${ }^{9}$

\footnotetext{
${ }^{8}$ Abdurrahman Wahid, Bunga Rampai Pesantren, (Jakarta: CV. Dharma Bhakti, 1979), h. 73.

${ }^{9}$ Abdurrahman Wahid, Bunga Rampai..., h. 3.
} 
Hal lain yang merupakan ciri kehidupan pesantren adalah pola hidup yang sederhana dan sikap tunduk dan patuh kepada kyai atau guru yang terkadang dilakukan secara berlebihan. Kyai sebagai pendiri, sekaligus pelaksana dan guru, serta santri secara langsung diberi pelajaran oleh kyai, dan tinggal bersamanya untuk jangka waktu beberapa lama, tinggal di asrama, termasuk ciri tersendiri bagi kehidupan dunia pesantren. ${ }^{10}$

\section{Urgensi Pembahasan}

Tulisan ini membahas tentang Sistem Pesantren (dayah) Salafi menjadi sangat menarik untuk dibahas mengingat pesantren merupakan lembaga pendidikan Islam tertua di mana banyak berbagai generasi dan tokoh lahir dan muncul melalui lembaga pendidikan Islam yaitu Pesantren. Selain itu, arus transformasi global di mana berbagai lembaga pendidikan mau tidak mau mengikuti berbagai transformasi khususnya bidang pendidikan sesuai dengan kebutuhan zaman sehingga banyak lembaga pendidikan terjadi perubahan dari berbagai hal, mulai dari fasilitas, media pembelajaran maupun dalam penggunaan metode telah banyak mengalami perubahan karena dituntut oleh kebutuhan zaman.

\section{Pembahasan Sistematikan Pembahsan}

Bagian pertama dalam studi ini akan membahas tentang latar belakang sepintas tentang pesantren, pentingnya pemilihan judul dalam makalah ini. Pada bagian kedua akan dibahas tentang apa saja faktor-faktor penghambat kemajuan sebuah pesantren dan faktor-faktor yang memajukan sebuah pesantren sehingga dalam bab ini akan membahas kekuatan, kelemahan,

\footnotetext{
${ }^{10}$ Manfred Ziemek, Pesantren Dalam Perubahan SosiaS, Terj. Butche Soendjojo, Judul asli, Pesantren Islamische Bildung in Sozialen Wandel, (Jakarta: P3M, 1986), h.100
} 
tantangan dan peluang sebuah pesantren. Bab ketiga merupakan penutup, di mana dalam bab ini akan membuat sebuah kesimpulan isi tulisan ini sehingga pembaca dapat memahami substansi makakah dengan jelas. Dalam bab tiga ini juga akan memberikan beberapa saran dan rekomendasi tentang pesantren.

\section{E. Faktor - Faktor Penghambat Kemajuan Pesantren Manajemen dan Kurikulum Pesantren}

Pesantren yang diakui sebagai model pendidikan awal (Islam) di Indonesia sampai saat ini masih eksis dan diakui keberadaannya di masyarakat, meskipun tidak jarang di antara masyarakat membicarakan pengelolaan pendidikan pesantren yang masih kurang. Pengelolaan pesantren yang apa adanya tersebut mudah dilihat dari kurikulum sebagai pesantren yang belum dikembangkan dan disesuaikan dengan perkembangan ilmu dan teknologi. Sebagai akibatnya, para alumni pesantren juga sering kali gagap dalam menghadapi tantangan zaman. Sebagai contoh, tatkala ada sebagian alumni pesantren yang menjadi tokoh masyarakat sebagai politisi, mereka seakan gagap menghadapi perannya yang baru karena mereka memang belum atau bahkan tidak mengetahui betul bagaimana "konstruksi politik Islam" dan strategi berpolitik yang disebutsebut sebagai high politic. Hal tersebut terjadi karena materi kajian yang diberikan di pesantren kurang dikontekstualkan dengan perkembangan zaman seperti fih politik/fiqh as-siyasah belum diberikan secara baik dan terstrukturdalam bangunan kurikulum pesantren. ${ }^{11}$

Bukti pengelolaan pesantren yang apa adanya adalah tenaga pengajar pesantren yang belum dipersiapkan secara sistematis sebagai ustad profesional yang menguasai maddah

${ }^{11}$ Moh. Roqib, Ilmu Pendidikan Islam (Yogyakarta: Lkis Yogyakarta, 2009) hal. 149 
dan sekaligus mampu mempraktikkan metode (thariqah) pembelajaran yang baik. Hal lain yang membuktikan lemahnya pengelolaan pesantren adalah jaringan sebagian pesantren juga diakui lemah, baik jaringan dengan sesama pesantren, masyarakat, pengusaha, maupun pemerintah. komunikasi yang dilakukan pesantren kurang intensif dan efektif. Hal lain yang bisa dijadikan bukti adalah rendahnya pengelolaan pembelajaran di pesantren bisa dilihat dari terbatasnya sarana dan prasarana yang dimilikinya. Padahal jika pesantren mampu meyakinkan stakeholder bahwa ia mampu menyiapkan santri yang berkualitas maka pesantren tersebut akan mudah membangun jaringan yang kuat, yang memungkinkan kebutuhannya akan sarana dan prasarana terpenuhi dengan baik. Hal ini sudah terbukti di beberapa pesantren yang telah maju dan besar sehingga mereka mampu menggalang dukungan dana dari masyarakat melalui wakaf dan lainnya. ${ }^{12}$

Meski banyak kelemahan yang dimiliki oleh pesantren, sebagian besar di antaranya masih tetap mendapatkan tempat di hati masyarakat muslim Indonesia, Terlebih lagi pesantren yang memiliki figur kharismatik, mampu menjaga kualitas keilmuannya, berkonsentrasi penuh terhadap perkembangan keilmuannya para santri, dan mampu membangun komunikasi yang baik dengan komunitas sosial dan pemerintah. ${ }^{13}$

\section{F. Faktor yang Memajukan Pesantren}

\section{Transformasi dan Pembaharuan Pesantren}

Secara bahasa, kata tajdid berarti pembaharuan. Dalam bahasa Arab, sesuatu dikatakan "jadid" (baru), jika bagianbagiannya masih erat menyatu dan masih jelas. Maka upaya tajdid seharusnya adalah upaya untuk

\footnotetext{
${ }^{12}$ Moh. Roqib, Ilmu Pendidikan..., hal 150

${ }^{13}$ Moh. Roqib, Ilmu Pendidikan.. ., hal 151
} 
mengembalikan keutuhan dan kemurnian Islam kembali. Dalam hal ini tajdid adalah koreksi ulang atau konseptualisasi ulang pada hakikatnya selalu berorientasi pada pemurnian yang sifatnya kembali pada ajaran asal dan bukan adopsi pemikiran asing, dalam pelaksanaannya diperlukan pemahaman yang dalam akan paradigma dan pandangan hidup islam yang bersumber dari Al-Quran dan Sunnah, serta pendapat para ulama terdahulu yang secara ijmak dianggap shahih. Pembaharuan Islam bukanlah sesuatu yang evolusioner, melainkan lebih cenderung devolusioner, dengan artian bahwa pembaharuan bukan merupakan proses perkembangan bertahap di mana yang datang kemudian lebih baik dari sebelumnya. ${ }^{14}$

Harun Nasution menyebut gerakan pembaharuan pemikiran Islam dengan istilah modernisasi pemikiran Islam yang mempunyai arti, seperti dikutip Azyumardi Azra sebagai suatu aliran, gerakan, pemikiran, dan usaha untuk mengubah paham, adat istiadat agar semuanya disesuaikan dengan pendapat dan keadaan baru yang timbul oleh kemajuan ilmu pengetahuan serta teknologi modern. Adapun modernisasi menurut KBBI, adalah suatu proses pergeseran sikap dan mentalitas sebagai warga masyarakat untuk bisa hidup sesuai dengan tuntutan hidup masa kini. ${ }^{15}$ Berbeda dengan Harun Nasution, Maulana Maududi menyebut pembaruan pemikiran Islam dengan istilah tajaddud-tajdid, istilah tersebut diartikan sebagai suatu gerakan pemurnian yang merupakan reaksi atas melemah dan membekunya karena ancaman dari luar, menurut

${ }^{14}$ Tabrani. Za, Sistem Pemikiran Pendidikan Islam Di Indonesia, Dalam Journal Falsafah At-Ta 'Lim Vol. 6, no 2 Agustus 2012, hal. 83

${ }^{15}$ Abd. Rachman Assegaf, Pendidikan Islam Kontekstual (Yogyakarta: Pustaka Pelajar, 2010) hal. 88 
Maulana Maududi, suatu gerakan bisa disebut sebagai pembaruan jika:

a. Merupakan usaha perbaikan kondisi masyarakat dengan membersihkan penyakit yang meracuninya.

b. Mencari letak permasalahan untuk menyelesaikannya.

c. Identifikasi kemampuan dirinya untuk melakukan pembaruan.

d. Upaya menciptakan perombakan pandangan dan pola berpikir masyarakat kearah yang lebih baik.

e. Upaya perbaikan secara praksis.

f. Active dan responsive mengembangkan aplikasi Islam.

g. Merombak secara Internasional. ${ }^{16}$

Berdasarkan asumsi bahwa pembaruan pendidikan Islam bersumber dari upaya pembaruan pemikiran Islam, maka pembaruan pendidikan Islam diartikan sebagai pembaruan pemikiran yang dilakukan dalam bidang pemikiran maupun praktek pendidikan Islam. Dengan makna ini, pendapat manapun mengenai pembaruan pemikiran dapat disubstitusikan. Gerakan pembaruan pada dasarnya mengusung nilainilai seperti: nilai pembaruan, nilai perjuangan, nilai kemerdekaan pikiran agama dan pikiran, nilai persatuan dan solidaritas.

2. Beberapa Model Transformasi dan Pembaharuan Pesantren

Pesantren merupakan lembaga pendidikan Islam yang tertua di Indonesia, disinyalir sebagai sistem pendidikan yang lahir dan tumbuh melalui kultur Indonesia yang bersifat "indogenous", yang mana telah mengadopsi model pendidikan sebelumnya yaitu dari pendidikan Hindu dan Budha sebelum kedatangan Islam. $^{17}$ Pondok pesantren sebagai lembaga pendidikan Islam memiliki kekhasan, baik dari segi sistem

\footnotetext{
${ }^{16}$ Abd. Rachman Assegaf, Pendidikan Islam..., hal.88

${ }^{17}$ Maunah, Tradisi Intelektual Santri Dalam Tantangan Dan Hambatan Pendidikan

Pesantren Di Masa Depan (Yogyakarta: Teras, 2009) hal. 1
} 
maupun unsur pendidikan yang dimilikinya. perbedaan dari segi sistem, terlihar dari proses belajar mengajar yang cenderung sederhana, meskipun harus diakui ada juga pesantren yang memadukan sistem modern dalam pembelajarannya. ${ }^{18}$

Berdasarkan tujuan pendiriannya, pesantren hadir dilandasi sekurangkurangnya oleh dua alasan: pertama, pesantren dilahirkan untuk memberikan respons terhadap situasi dan kondisi sosial suatu masyarakat yang tengah pada runtuhnya sendisendi moral, melalui transformasi nilai yang ditawarkan (amar ma;ruf, nahyi munkar ). Kedua, salah satu tujuan pesantren adalah menyebarluaskan informasi ajaran tentang universalitas Islam ke seluruh plosok nusantara yang berwatak pluralis, baik dalam dimensi kepercayaan, budaya maupun kondisi sosial masyarakat. ${ }^{19}$

Di tengah kompetisi sistem pendidikan yang ada, pesantren sebagai lembaga pendidikan tertua yang masih bertahan hingga kini tentu saja harus sadar bahwa penggiatan diri yang hanya pada wilayah keagamaan tidak lagi memadai, maka dari itu pesantren harus proaktif dalam memberikan ruang bagi pembenahan dan pembaharuan sistem pendidikan pesantren dengan senantiasa harus selalu apresiatif sekaligus selektif dalam menyikapi dan merespons perkembangan dan pragmatisme budaya yang kian menggejala. Hal tersebut dapat dijadikan pertimbangan lain bagaimana seharusnya pesantren menyiasati fenomena tersebut dengan beberapa perubahan pesantren di bawah ini:

3. Perubahan Kurikulum Pesantren

Model Pembelajaran pesantren pada mulanya populer menggunakan metodikdidaktif dalam bentuk sorogan,

${ }^{18}$ Amirudin Nahrawi, Pembaharuan Pendidikan Pesantren (Yogyakarta: Gama media, 2008) hal. 23

${ }^{19}$ Maunah, Tradisi Intelektual... Hal 25-26 
bandongan, halaqah dah hafalan. Menurut Mastuhu pembaharuan metode pembelajaran mulai terjadi sekitar awal abad ke-20 atau tepatnya sekitar tahun 1970-an, dari pola sorogan berubah menjadi sistem klasikal, tidak hanya itu, beberapa pendidikan keterampilan juga mulai masuk ke dunia pesantren, seperti bertani, beternak, kerajinan tangan mulai akrab dalam kehidupan santri sehari-hari. Ini dimaksudkan untuk mengembangkan wawasan atau orientasi santri dari pandangan hidup yang selalu berpandangan ukhrawi, supaya seimbang dengan kehidupan duniawi. ${ }^{20}$

4. Pembaharuan Redesign Kurikulum Pesantren

Pada umumnya pesantren sebagai lembaga pendidikan

Islam, materi pembelajarannya lebih mengutamakan pelajaran agama Islam yang bersumber dari kitab-kitab klasik, seperti tauhid, hadis, tafsir, fiqih dan sejenisnya. Kurikulum didasarkan pada tingkat kemudahan dan kompleksitas kitab-kitab yang dipelajari, mulai dari tingkat awal, menengah dan lanjut. ${ }^{21}$ Dalam perkembangannya, hampir setiap pesantren telah melakukan pembaharuan kurikulum dengan memasukkan pendidikan umum dalam kurikulum pesantren. Sifatnya bervariasi, ada pesantren yang memasukan pendidikan 30\% agama dan $70 \%$ umum, ada pula yang sebaliknya, yakni $80 \%$ agama dan sisanya pelajaran

umum.

5. Pembaharuan Evaluasi Kurikulum Pesantren

Kemampuan santri biasanya dievaluasi dengan keberhasilannya mengajarkan kitab kepada orang lain. Apabila audiensi merasa puas, maka santri yang bersangkutan dinilai telah lulus. Legalisasi kelulusannya adalah restu kiai bahwa santri tersebut diizinkan pindah untuk mempelajari kitab lain yang lebih tinggi tingkatannya dan boleh mengajarkan kitab

${ }^{20}$ Amirudin Nahrawi, Pembaharuan Pendidikan..., hal. 28

${ }^{21}$ Amirudin Nahrawi, Pembaharuan Pendidikan. ., hal. 28 
yang dikuasainya kepada yang lain. Pesantren yang telah mengadopsi pembaruan kurikulum, baik yang mengacu pada Departemen Agama maupun Departemen Pendidikan Nasional jelas telah meninggalkan model evaluasi tersebut. Model madrasi/klasikal evaluasinya sebagaimana madrasah pada umumnya, yaitu menggunakan ujian resmi dengan memberikan angka-angka kelulusan serta tanda kelulusan seperti ijazah. ${ }^{22}$

6. Pembaharuan Organisasi/Manajemen

Dalam konteks pembaharuan manajemen, meskipun peran kiai tetap dipandang penting, tetapi kiai tidak ditempatkan pada posisi penentu kebijakan secara tunggal. Dari sini kerja dimulai dengan pembagian unit-unit kerja sesuai urutan yang ditetapkan pimpinan pesantren. Ini berarti kekuasaan kiai telah terdistribusi kepada yang lain yang dipercaya untuk mengemban tugas, mekanisme kerja juga mulai diarahkan sesuai dengan visi dan misi pesantren. Berangkat dari hal tersebut, terkadang tetap diakui bahwa pola perencanaan pesantren umumnya masih tergolong sederhana, sering kali program jangka pendek, menengah, dan jangka panjang tampak tumpang tindih. Akibatnya, program-program demikian sulit diukur tingkat pencapaiannya. ${ }^{23}$

7. Prinsip-Prinsip Pembaharuan yang harus ditegakkan Pesantren

Proses globalisasi adalah suatu proses menuju keadaan budaya global yang pasti setuju atau tidak setuju memasuki budaya Indonesia yang pada akhirnya akan mengubah hal-hal yang mendasar dalam pandangan hidup dan mencukupi seluruh aspek kehidupan. Berangkat dari hal tersebut, KH. Ali Maksum menyatakan delapan prinsip-prinsip yang terlihat dan harus diterapkan dalam pembaruan pendidikan pesantren, yaitu: ${ }^{24}$

\footnotetext{
${ }^{22}$ Amirudin Nahrawi, Pembaharuan Pendidikan. ., hal. 30

${ }^{23}$ Amirudin Nahrawi, Pembaharuan Pendidikan. .., hal. 30-31

${ }^{24}$ Tabrani. Za, Sistem Pemikiran Pendidikan..., hal. 85-87
} 
a. Memiliki kebijaksanaan menurut ajaran Islam. Para santri dibantu agar mampu memahami makna hidup, keberadaan, peranan, serta tanggung jawabnya dalam kehidupan di masyarakat.

b. Memiliki kebebasan yang terpimpin. Setiap manusia memiliki kebebasan, tetapi kebebasan itu harus dibatasi karena kebebasan memiliki potensi anarkisme. Keterbatasan (ketidakbebasan) mengandung kecenderungan mematikan kreativitas, berangkat dari hak tersebut, maka pembatasan harus dibatasi. Inilah yang dimaksud kebebasan yang terpimpin, dan kebebasan inilah yang dibentuk oleh K.H. Ali Maksum dalam mengasuh santrinya.

c. Berkemampuan mengatur diri sendiri. Pada umumnya santri harus dapat mengatur diri sendiri dan kehidupannya menuruti batasan yang telah diajarkan agama.

d. Memiliki rasa kebersamaan yang tinggi. Dalam hal kewajiban santri harus menunaikan kewajiban terlebih dahulu, sedangkan dalam hak-hak, para santri harus mendahulukan kepentingan orang lain sebelum kepentingan sendiri.

e. Menghormati orang tua dan guru. Ini memang ajaran Islam, tujuan ini dicapai antara lain melalui penegakan berbagai pranata di pesantren seperti mencium tangan guru, tidak membantah guru. Demikian juga terhadap orang tua, karena nilai-nilai ini sudah banyak terkikis di sekolah sekolah.

f. Cinta kepada ilmu. Menurut Al-Quran ilmu (pengetahuan) datang dari Allah, banyak hadis yang mengajarkan pentingnya menuntut ilmu dan menjaganya, maka dari itu para santri harus memandang ilmu sebagai sesuatu yang suci dan tinggi. 
g. Mandiri. Apabila mengatur diri sendiri kita sebut otonomi, maka mandiri yang dimaksud adalah berdiri atas kekuasaan sendiri, sejak awal santri telah dilatih untuk mandiri, seperti kebanyakan masak sendiri, mengatur uang belanja sendiri, mencuci pakaian sendiri dan sebagainya.

h. Kesederhanaan. Dilihat secara lahiriah sederhana memang mirip dengan kemiskinan, padahal yang dimaksud sederhana contohnya di Pesantren Krapyak adalah sikap hidup, yaitu sikap memandang sesuatu, terutama materi secara wajar, proporsional dan fungsional. Sebenarnya banyak para santri yang berlatar belakang orang kaya, mereka dilatih hidup sederhana. Ternyata orang kaya tidak sulit menjalani kehidupan sederhana bila dilatih seperti di kehidupan pesantren, apa yang melatih mereka? kondisi pesantren itulah yang melatih mereka. Di sini kita melihat bahwa pesantren adalah suatu sistem; yang kondisi itu merupakan salah satu elemennya. kesederhanaan itu sesungguhnya realisasi keimanan dari ajaran Islam yang pada umumnya telah diajarkan para sufi. Hidup secara sufi memang merupakan suatu yang khas pada umumnya.

\section{G. Kesimpulan}

Pesantren sebagai lembaga pendidikan tertua yang masih bertahan hingga kini tentu saja harus sadar bahwa penggiatan diri yang hanya pada wilayah keagamaan tidak lagi memadai, maka dari itu pesantren harus proaktif dalam memberikan ruang bagi pembenahan dan pembaharuan sistem pendidikan pesantren dengan senantiasa harus selalu apresiatif sekaligus selektif dalam menyikapi dan merespons perkembangan dan pragmatisme budaya yang kian menggejala sehingga sangat diperlukan pembaharuanpembaharuan yang harus dilakukan 
pesantren dalam menghadapi zaman modern, adapun pembaharuan-pembaharuan tersebut bisa dilakukan pada:

1. Pembaharuan Metode pembelajaran

2. Pembaharuan Kurikulum

3. Pembaharuan Evaluasi

4. Pembaharuan Organisasi/Manajemen

Tantangan tunggal pesantren di masa modern adalah adanya gesekan-gesekan globalisasi atau bisa disebut dengan tantangan modernisasi yang bersifat kompleks. Dalam menghadapi tantangan zaman, pesantren juga harus senantiasa memegang prinsip-prinsip pembaharuan yaitu: memiliki kebijaksanaan menurut ajaran Islam, memiliki kebebasan yang terpimpin, berkemampuan mengatur diri sendiri, memiliki rasa kebersamaan yang tinggi, menghormati orang tua dan guru, cinta kepada ilmu, mandiri, kesederhanaan.

\section{H. Rekomendasi}

Berangkat dari kenyataan, jelas pesantren di masa yang akan datang dituntut berbenah, menata diri dalam menghadapi persaingan bisnis pendidikan yang telah dilakukan oleh Muhammadiyah dan lainnya, tapi perubahan dan pembenahan yang dimaksud hanya sebatas manajemen dan bukan coraknya apalagi berganti baju dari salafiyah ke mu"asyir (modern), karena hal itu hanya akan menghancurkan nilai-nilai positif pesantren seperti yang terjadi sekarang ini, salah satunya yaitu lulusannya tidak dapat mengaji. maka idealnya pesantren ke depan harus dapat mengimbangi tuntutan zaman dengan mempertahankan tradisi dan nilai-nilai kesalafannya. Pendidikan pesantren harus terus dipertahankan, khususnya pembelajaran kitab kuning dari Ibtidaiyah sampai Aliyah sebagai kegiatan belajar mengajar wajib bagi santri dan mengimbanginya dengan pengajian tambahan, kegiatan 
ekstrakulikuler seperti kursus komputer, bahasa Inggris, skill lainnya dan pengadaan program paket $\mathrm{A}, \mathrm{B}$, dan $\mathrm{C}$ untuk mendapatkan ijazah formalnya atau dengan menjalin kerja sama dengan sekolah lain untuk mengikuti persamaan, apabila ini terjadi, maka pesantren akan lebih banyak melahirkan cendekiawancendekiawan yang berbekal ilmu agama serta ilmu sosial yang akan bermanfaat, karena pendidikan pesantren merupakan pendidikan yang unik dengan beberapa kelebihan yang dimilikinya dari pendidikan lain, adapun kelebihannya antara lain:

1. Pesantren merupakan lembaga pendidikan tempat memperdalam ilmu agama islam, agar dapat melestarikan ilmuilmu tersebut dengan tujuan menjadi kader ulama, pemimpin umat dan pemimpin bangsa.

2. Pesantren menggunakan sorogan dan halaqah (ceramah) dengan metode tersebut menyimpulkan bahwa kemampuan akan menghafal sekian banyak ayat, hadits, dan pelajaranpelajaran lainnya di luar kepala.

3. Dapat melestarikan kitab-kitab klasik tersebut, juga setidaktidaknya mampu memahami bahasa aslinya (bahasa Arab).

4. Dapat menerima (ikhlas) dengan kekurangan sarana dan prasarana yang dimiliki pesantren serta semangat juang yang menggebu-gebu untuk menutupi kekurangan dan berusaha untuk mengatasinya, dan keberadaannya yang dibutuhkan masyarakat. 